\title{
Конструктивно-технологічні рішення забезпечення статичної міцності та ресурсу регіональних пасажирських літаків
}

\author{
* Державне підприємство "Антонов» \\ ** Національний аерокосмічний університет ім. М.Є. Жуковського \\ «Харківський авіаційний інститут»
}

Забезпечення безпеки польотів і ресурсу конструкцій авіаційної техніки є однією 3 актуальних проблем створення сучасних регіональних пасажирських літаків. Ця робота присвячена відображенню аспектів забезпечення статичної міцності та ресурсу регіональних пасажирських літаків. Проведено аналіз факторів і чинників, котрі впливають на статичну міцність, ресурс літального апарата, серед яких - втома, корозія, знос, фрретинг-корозія, людський чинник. Для забезпечення статичної міцності визначено експлуатаційні й розрахункові навантаження для всього діапазону розрахункових швидкостей і висот польоту, перевантажень, ваг і центрувань літака, ваги палива, ваги вантажу й різних можливих в експлуатації комбінацій їх розподілу, з урахуванням: динамічного навантаження й пружних характеристик конструкції літака при польоті в неспокійному повітрі й при посадці; динамічного навантаження конструкції системи керування при маневруванні та поривах вітру; відмов і несправностей систем, що безпосередньо впливають на характеристики міцності. Результати льотних випробувань показали, що типова конструкція літаків Ан-148100/Ан-158 за умовами статичної міцності не має особливостей і частин, які створюють аварійні умови або є ненадійними, та підтвердили правильність вибору встановлених експлуатаційних обмежень, поданих для внесення в Керівництво з льотної експлуатації. Визначення умов відпрацьовування літаками сімейства Ан-148-100/Ан-158 проектного терміну служби 30 років виконано на основі порівняльного аналізу корозійної стійкості конструкцій літаків «Ан», термін служби яких перевищує 30 років. Літаки Ан-148-100/Ан-158 спроектовані та виготовляються у всекліматичному виконанні з дотриманням усіх вимог щодо антикорозійного захисту. У літаках застосовано конструкторські та технологічні рішення із захисту від зниження міцності в процесі експлуатації від атмосферних впливів, корозії й стирання, що дозволило констатувати, що основні силові елементи типової конструкції літаків Ан-148-100/Ан-158 захищені від зниження або втрати міцності в процесі експлуатації 3 будь-якої причини, включаючи атмосферні впливи, корозію й стирання, а також забезпечені достатніми засобами вентиляції й дренажування. Забезпечення статичної міцності та ресурсу регіональних пасажирських літаків підтверджено статичними, втомними та льотними випробуваннями літаків, що знайшло своє відображення у технічних звітах із міцності, ресурсу та термінів служби літаків Ан-148-100/Ан-158.

Ключові слова: регіональний пасажирський літак, конструктивно-технологічний метод, статична міцність, ресурс.

Забезпечення безпеки польотів і ресурсу конструкцій авіаційної техніки є однією з актуальних проблем створення літальних апаратів. Задані статична міцність, ресурс і надійність авіаційної техніки закладаються при проектуванні та конструюванні, забезпечуються в процесі виробництва та досягаються під час експлуатації.

Проектування сучасної авіаційної техніки за принципом припустимості пошкоджень $€$ комплексною науково-технічною проблемою, яка вирішується на основі інтеграції наукових досліджень фахівців авіаційної промисловості і наукових центрів. 
Головними чинниками, які призводять до порушення характеристик працездатності або відмов деталей, вузлів і агрегатів авіаційної техніки, є: втома, корозія, знос, фретинг-корозія, людський чинник. Ці чинники значною мірою залежать від стану поверхні, її фрізичних і хімічних властивостей. Керуючи властивостями поверхні, вдається поліпшити втомні, триботехнічні та корозійні характеристики авіаційних конструкцій.

Руйнування конструктивних елементів від втоми $\epsilon$ результатом дії циклічних, динамічних навантажень і додаткових чинників (конструктивних, експлуатаційних, виробничих, навколишнього середовища, якості матеріалу, покриттів, технологічності виробництва, контролю стану конструкції впродовж забезпечення ії̈ життєвого циклу) [2 - 7].

Досвід експлуатації авіаційної техніки показує, що повністю виключити корозію авіаційних матеріалів неможливо. Виходячи 3 характерних типів корозійного пошкодження і місця розташування конкретного конструктивного елемента при проектуванні вибирають матеріал конструкції, схему його покриття, вибір конструктивного рішення з урахуванням корозійної поведінки, терміни виконання періодичних оглядів і регламентних робіт.

Питання зношування для деталей механізмів авіаційної техніки $€$ актуальними. Розрізняють такы види зношування: окислювальний, адгезійний, абразивний, ерозійний, фретинг-знос. Найбільш небезпечним для вузлів авіаційної техніки є фрретинг [2, 7].

Безпечна експлуатація за умов міцності реалізується на основі принципу припустимості пошкоджень. Припустимість пошкоджень передбачає гарантію безпеки конструкції шляхом встановлення термінів її огляду в експлуатації для виявлення можливих пошкоджень і ремонту або заміни пошкоджених елементів перш ніж дефекти та пошкодження досягнуть критичних розмірів і призведуть до руйнування конструкції.

При виборі конструкційних матеріалів для забезпечення ресурсу необхідно враховувати їх статичну міцність, пластичність, опір втомі, статичну та циклічну тріщиностійкість, корозійну стійкість, опір корозійному розтріскуванню під напруженням, корозійно-механічну втому, зносостійкість, опір фрретинг-втомі.

Згідно з авіаційними правилами [1] оцінювання міцності, рівня проектування й якості виробництва необхідно показати, що аварійної або катастрофічної ситуації через втому, корозію, дефекти виробництва або випадкове пошкодження можна уникнути протягом всього часу експлуатації авіаційної техніки. Ця оцінка має бути проведена для основних силових елементів (Principal structural element, PSE), які сприймають значну частину навантажень в польоті та на землі або навантажень надлишкового тиску, руйнування яких може призвести до аварійної або катастрофічної ситуації. До таких елементів належать деталі крила, оперення, поверхні керування та їх системи, фрюзеляжу, кріплення двигуна, шасі та їх основні вузли кріплення. При проведенні оцінювання мають бути використані відповідні запаси (коефіцієнти надійності).

Кожен аналіз має ґрунтуватись на такому:

- типовому спектрі навантажень, температурах і вологостях, очікуваних у експлуатації;

- переліку основних силових елементів і окремих вузлів конструкції (та їх критичних місць), руйнування яких може призвести до аварійної або катастрофрічної ситуації; 
- результатах випробувань, як правило, натурних, i розрахунках основних силових елементів конструкції і окремих вузлів;

- даних експлуатації літаків аналогічних типів.

Вся силова конструкція літака має відповідати вимогам припустимості пошкоджень. Виняток можуть становити ті частини (елементи, деталі) конструкції, де вимоги припустимості пошкоджень практично нездійснимі. Наприклад, деталі шасі.

Для місць конструкції, критичних за умовами втомної міцності, на стадії проектування має передбачатися забезпечення опору втомі з урахуванням значень проектного ресурсу. Рекомендується забезпечувати інтервал до першого огляду за умовами опору втоми не меншим, ніж 50\% проектного ресурсу. Для цього належить звертати увагу на вибір відповідного матеріалу, загальну напруженість конструкції, максимально можливе зниження концентрації напруження, а також на максимальне підвищення опору втомі на основі використання відповідних конструктивно-технологічних заходів. Технологічні процеси виготовлення елементів конструкції літака і їх складання мають бути такими, щоб забезпечувалася стабільність характеристик, що впливають на працездатність і опір втомі у межах встановлених ресурсів в очікуваних умовах експлуатації.

Ефективність заходів перевіряється лабораторними випробуваннями окремих конструктивних елементів (вузлів, стиків, панелей, відсіків та ін.).

Для критичних за умовами корозійної міцності місць конструкції, що встановлюються на основі наявного досвіду, при проектуванні має бути передбачений ефективний антикорозійний захист. Одночасно слід звернути увагу на вибір відповідного конструкційного матеріалу, врахувати його чутливість до корозії під напруженням і до інших видів корозії, а також розглянути ступінь агресивності навколишнього середовища. Особливу увагу слід звернути на поверхні стикуючих елементів, що допускають взаємне переміщення в процесі навантаження, а також на ті елементи конструкції, в яких можливе виникнення корозії під напруженням, де необхідно передбачити заходи, що забезпечують відсутність значних внутрішніх залишкових напружень (монтажних, зварювальних, технологічних та ін.).

За результатами робіт має бути проведено відповідний аналіз і обґрунтовано спроможність і умови (заходи) відпрацювання літаком проектного ресурсу. Слід розробити й обґрунтувати процедуру (систему) забезпечення та підтримки безпеки конструкції за умовами міцності при тривалій експлуатації на основі урахування й аналізу результатів досліджень, випробувань і накопичуваного досвіду експлуатації літаків даного типу. Як така процедура для вітчизняних літаків, котрі експлуатуються у зарубіжних країнах, рекомендується використовувати вказівки п. 7 МОСу з приводу поетапного встановлення та збільшення призначених ресурсів (термінів служби). В інших випадках, наприклад при продажу вітчизняних літаків за рубіж або експлуатації зарубіжних літаків, можуть бути розроблені інші процедури, що забезпечують еквівалентну безпеку, у тому числі і з урахуванням досвіду світової авіаційної спільноти.

Проектування, виробництво, випробування і експлуатація високоресурсної авіаційної техніки за принципом безпечної пошкоджуваності потребують зусиль багатьох учених та інженерів, що володіють методологією інтегрованого проектування, виробництва та інженерного аналізу за допомогою систем CAD/CAM/CAE/PLM. 
У статті надані лише деякі результати досліджень авторів і рекомендації щодо забезпечення статичної міцності та втомної довговічності регіональних пасажирських літаків Ан-148 та Ан-158 (рисунки 1, 2).

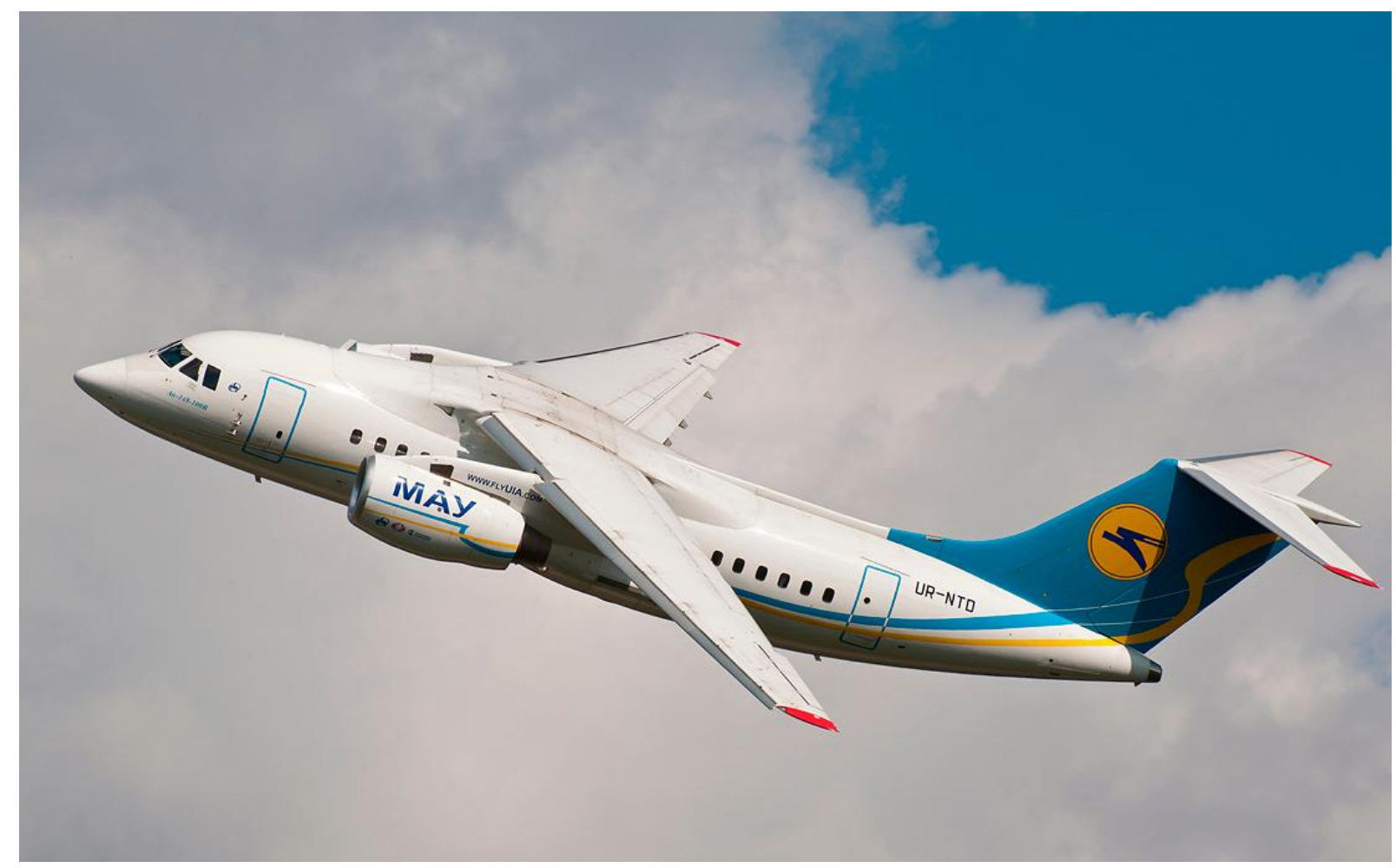

Рисунок 1 - Регіональний пасажирський літак Ан-148

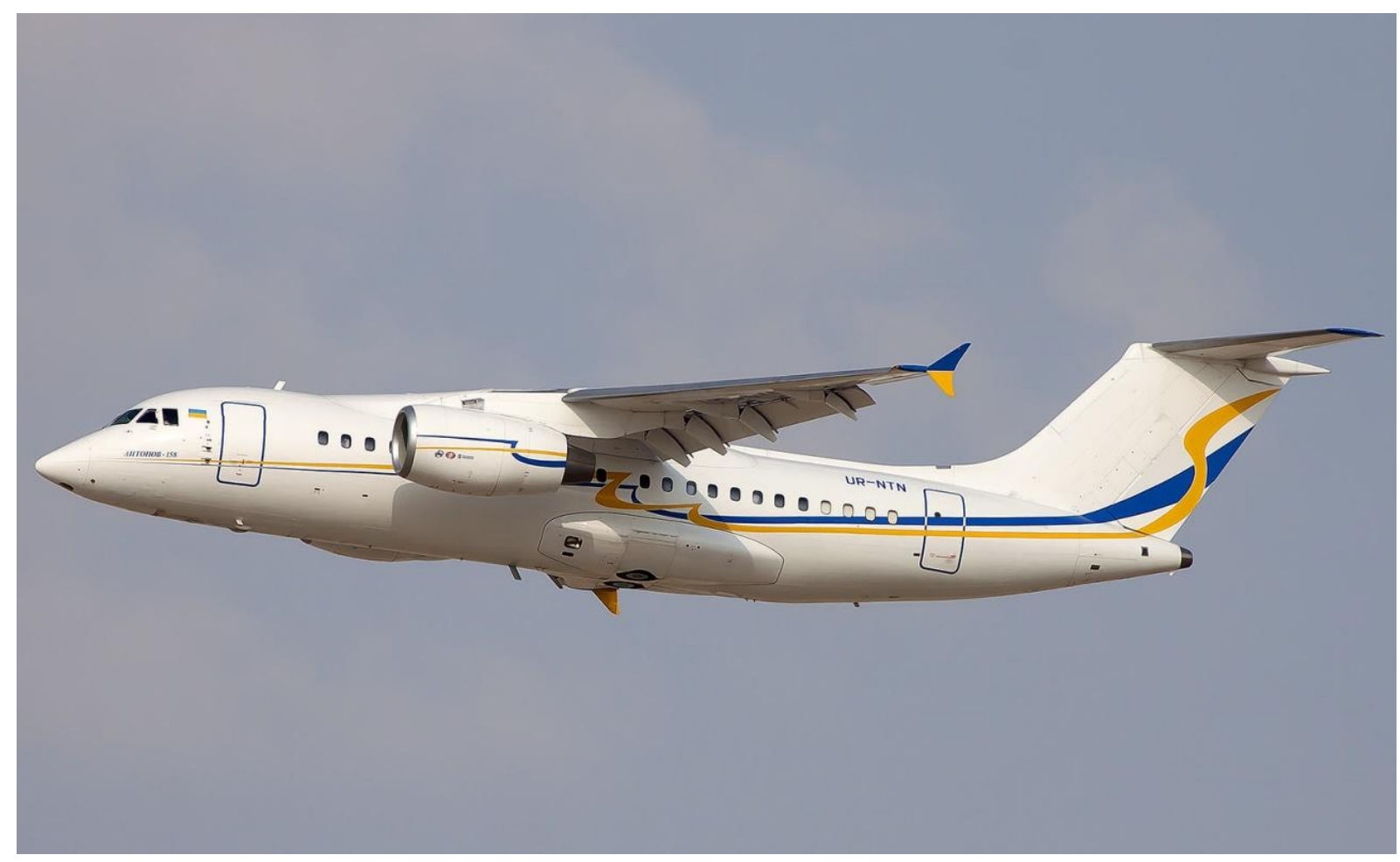

Рисунок 2 - Регіональний пасажирський літак Ан-158 


\section{Забезпечення статичної міцності}

Розроблення конструкції планера й систем виконувалося за авіаційними правилами АП-25 [1]. Експлуатаційні й розрахункові навантаження (експлуатаційні навантаження, помножені на відповідні коефіцієнти безпеки) визначені запропонованим способом для всього діапазону розрахункових швидкостей і висот польоту, перевантажень, ваг і центрувань літака, ваги палива, ваги вантажу й різних можливих в експлуатації комбінацій їх розподілу, з урахуванням:

- динамічного навантаження й пружних характеристик конструкції літака при польоті в неспокійному повітрі й при посадці;

- динамічного навантаження конструкції системи керування при поривах вітру на землі;

- відмов і несправностей систем, що безпосередньо впливають на характеристики міцності (§25.302 сертифікаційного базису СБ-148).

Застосовані надійні методи визначення інтенсивності й розподілу навантажень і їх зрівноважування в польотних і наземних випадках навантаження 3 урахуванням впливу пружних деформацій конструкції.

Для визначення аеродинамічних навантажень, що діють у розрахункових випадках навантаження, використані результати випробувань моделей літака Ан-148 в аеродинамічних трубах Т-106 ЦАГІ й АТ-1 ДП «АНТОНОВ» (рисунок 3).
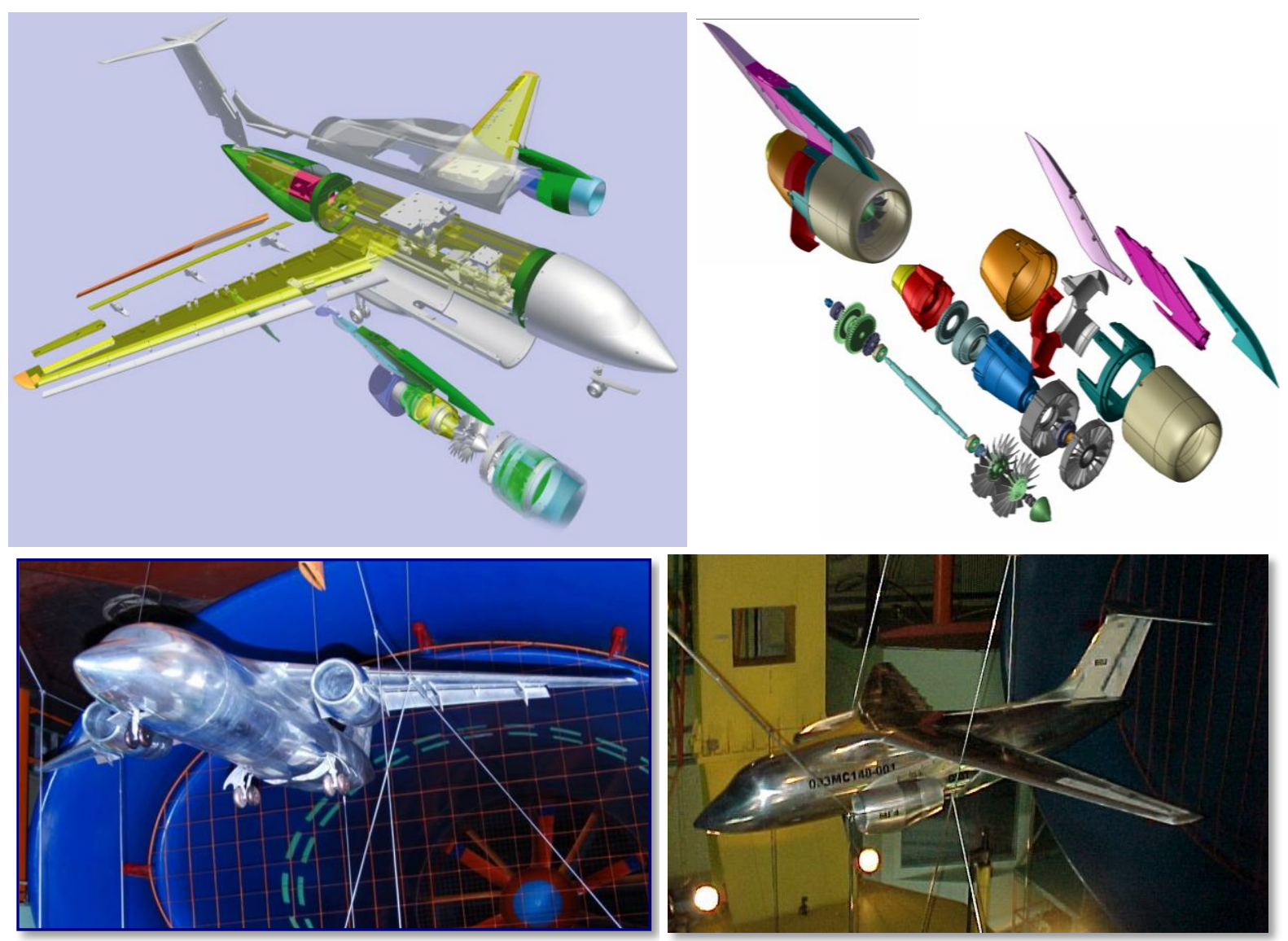

Рисунок 3 - Дослідження моделей у аеродинамічних трубах

Прийняті значення навантажень підтверджені результатами льотних випробувань літаків Ан-148 № 0101 і № 01-02. За результатами льотних випро- 
бувань літака Ан-148 визначено також рівень навантажень, що виникають при бафтингу й вібраціях при досягненні літаком граничних швидкостей або швидкостей звалювання.

У наземних випадках навантаження вибрані характеристики амортизації шасі перевірені копровими випробуваннями основного й носового шасі. Достатній рівень прийнятих навантажень на шасі й конструкцію літака в наземних випадках підтверджений результатами льотних випробувань літака Ан-148.

Розрахункові навантаження визначені також у випадках несправностей або відмов систем. Достатній рівень навантажень при різних відмовах, прийнятих у розрахунках, підтверджений результатами сертифікаційних випробувань літака за імітацією відмовних ситуацій.

Прийняті розрахункові умови забезпечення статичної міцності використані при встановленні експлуатаційних обмежень за міцністю.

Льотні випробування проведені на літаках Ан-148 № 01-01 і № 01-02. При сертифікаційних льотних випробуваннях здійснили вимірювання навантажень на всі основні агрегати літака у всіх діапазонах очікуваних умов експлуатації, включаючи випробування на граничних за умовами міцності режимах польоту, на режимах звалювання, при дослідженні швидкісних характеристик, визначенні границь бафттинг. За результатами льотних випробувань були підтверджені прийняті в розрахунках закономірності навантаження основних агрегатів літака: крила, механізації крила, хвостового оперення, установки двигуна, шасі, фрюзеляжу й системи керування.

Виміряні при льотних випробуваннях навантаження не перевищують максимальних експлуатаційних навантажень, прийнятих для забезпечення міцності.

Результати льотних випробувань показали, що типова конструкція літаків Ан-148100/Ан-158 за умовами статичної міцності не має особливостей і частин, які створюють аварійні умови або є ненадійними.

Результати льотних випробувань підтвердили правильність вибору встановлених експлуатаційних обмежень, наведених для внесення в Керівництво з льотної експлуатації (КЛЕ).

У конструкції літаків застосовані матеріали, стабільність властивостей яких гарантована виготовлювачами матеріалів і підтверджена Висновком Сертифрікаційного центру (СЦ) «Матеріал».

Для визначення характеристик міцності конструкцій 3 полімерних композиційних матеріалів (ПКМ) на етапі проектування використані базові розрахункові значення матеріалів (з використанням базису «В»), а також враховані технологічні особливості виготовлення конструкцій, деградація властивостей матеріалів при тривалому впливі кліматичних чинників і можливість виникнення локальних ушкоджень від механічних впливів шляхом уведення спеціальних коефіцієнтів зниження розрахункових значень. На літаках Ан-148-100/Ан-158 агрегати із застосуванням ПКМ виконані за типовими конструктивними схемами із застосуванням перевірених матеріалів і технологій, що використовувалися на сертифікованих літаках Ан-124, Ан-72, Ан-74, Ан-140, а також на літаку Ан-70, з урахуванням досвіду проектування й багаторічної експлуатації подібних конструкцій і відповідних ПКМ у різних кліматичних зонах. Матеріали й напівфабрикати паспортизовані й поставляються відповідно до затверджених технічних умов ВІАМ. Виготовлення й контроль елементів конструкції з композиційних матеріалів (КМ) здійснюються за відпрацьованою у 
ДП «АНТОНОВ» і впровадженою на серійному виробництві технологічною документацією, яка пройшла багаторічну перевірку при виробництві сертифікованих літаків «Ан». Якість виготовлення агрегатів із застосуванням КМ на серійному виробництві та їх міцність перевірені при статичних випробуваннях агрегатів літака Ан-148 №01-03 (секцій закрилка, передкрилка, відхилюваного носка, елерона, інтерцептора, рулів висоти й напрямку), які виготовлені на серійному заводі-виготовлювачі зазначених агрегатів.

Розрахунок міцності конструкцій із ПКМ проведений із застосуванням надійних методів розрахункового моделювання (у тому числі NASTRAN) (рисунок 4) і перевірений при статичних випробуваннях агрегатів із проведення тензометрії.

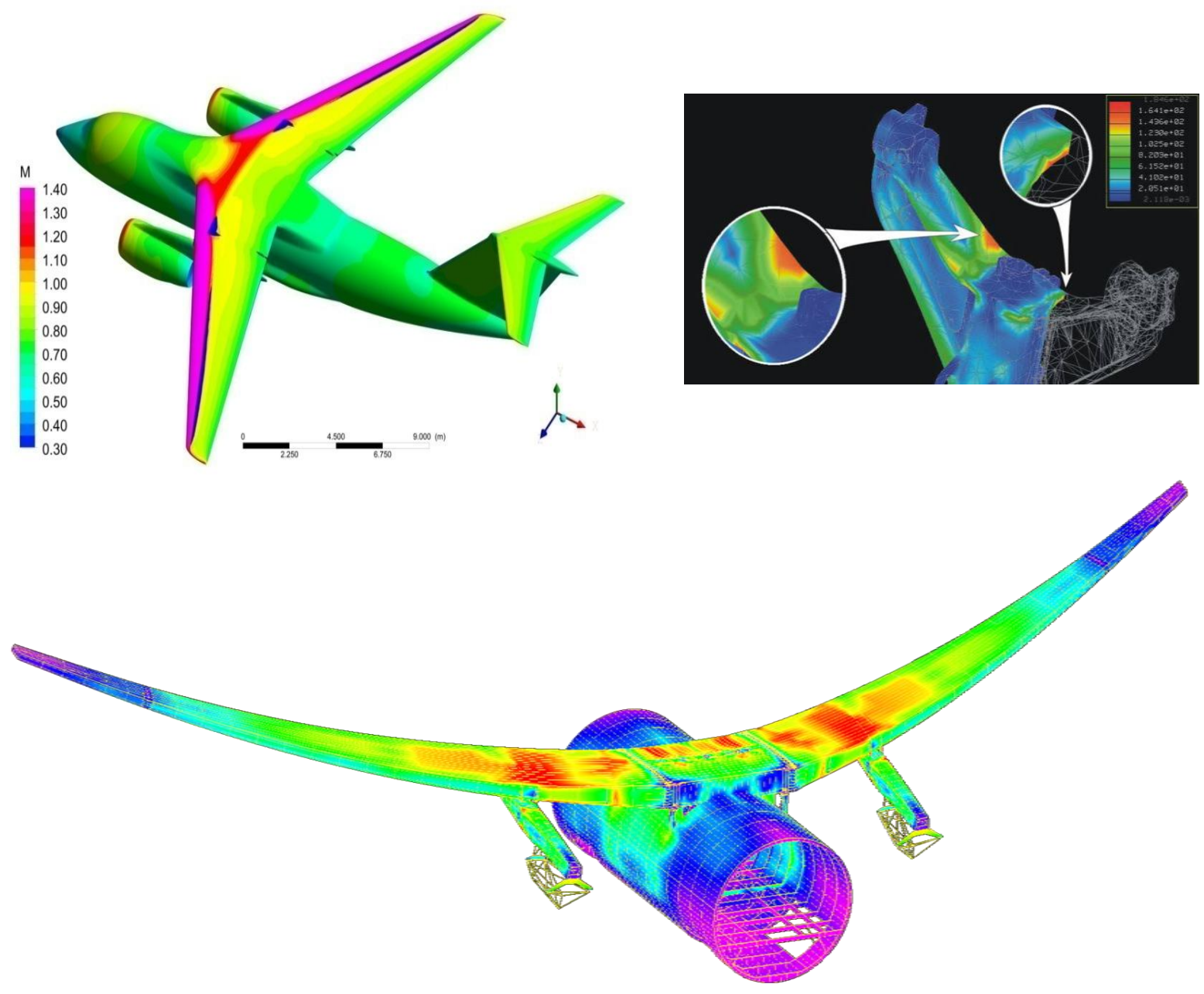

Рисунок 4 - Числові методи проектування та розрахунків

Характеристики міцності матеріалів та їх розрахункові значення, що визначені на підставі застосованих критеріїв, а також технологія виготовлення агрегатів задовольняють вимогам АП-25.

Статична міцність літаків Ан-148-100/Ан-158 типової конструкції підтверджена розрахунками міцності, статичними випробуваннями агрегатів літака Ан-148 № 01-03 і статичними випробуваннями окремих елементів конструкції літака Ан-148 № 01-03 на стендах.

Статичні випробування проведені на літаку Ан-148 №01-03 у лабораторії випробувань на міцність ДП «АНТОНОВ» (рисунок 5) за узгодженою із ЦАГІ 
Програмою містили навантаження конструкції експлуатаційними навантаженнями й навантаженнями аж до розрахункових протягом не менше 3 секунд із проведенням необхідних перевірок відповідно до вимог АП-25. Програма статичних випробувань виконана в повному обсязі.

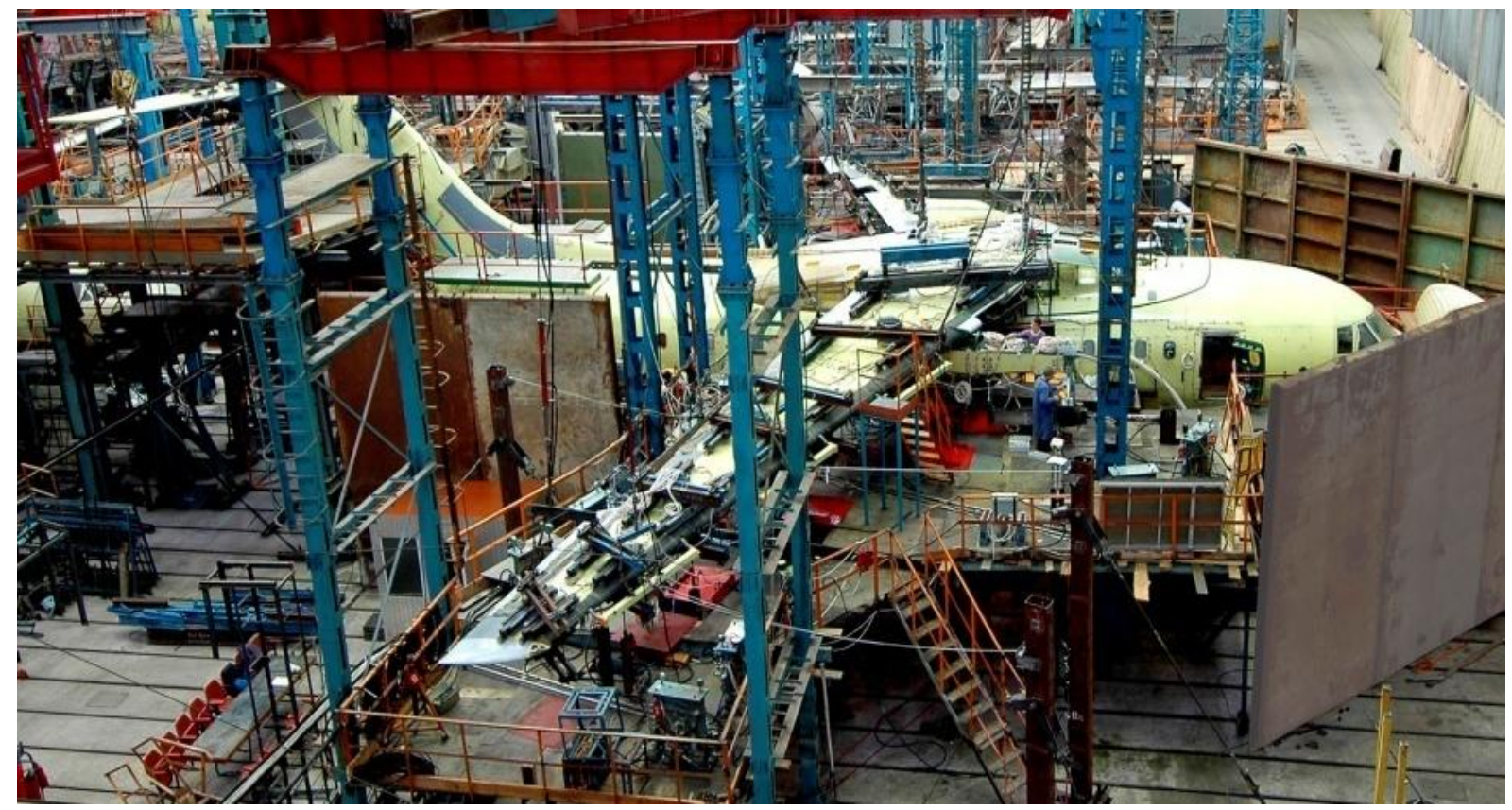

Рисунок 5 - Дослідження планера на міцність

Для використання результатів статичних випробувань літака Ан-148 № 01-03 при підтвердженні статичної міцності типової конструкції Ан-148-100 виконані такі розрахункові роботи:

- скінченно-елементний розрахунок на міцність агрегатів планера літака на максимальні експлуатаційні навантаження $\left(67 \% P_{P}\right)$ розрахункових випадків, реалізованих у ході статичних випробувань літака з виконанням тензометрії;

- порівняння отриманих при статичних випробуваннях результатів тензометрії елементів конструкції планера літака 3 відповідними результатами скінченно-елементного розрахунку на міцність.

Виконані розрахунки на міцність агрегатів планера типової конструкції Ан-148100/Ан-158 з урахуванням усіх доробок, спрямованих для впровадження в серійне виробництво, у розрахункових випадках навантаження з використанням моделей, уточнених за результатами порівняння тензометрії при статичних випробуваннях із скінченно-елементним розрахунком конструкції планера.

Визначення напружено-деформованого стану конструкції проводилося методом скінчених елементів з використанням редукування обшивки в стислих зонах. Критичні напруження загальної втрати стійкості визначалися 3 використанням діаграм деформування матеріалів і редукування обшивки, а також з урахуванням результатів випробувань на стиск натурних зразків панелей (трьохпрогонних).

Результати статичних випробувань показали, що типова конструкція літаків Ан-148100/Ан-158 за умовами статичної міцності не має особливостей і частин, які створюють аварійні умови або є ненадійними. 
При проведенні статичних випробувань після навантаження агрегатів експлуатаційними навантаженнями й їх зняття, а також додатково після проведення випробувань на максимальні навантаження виконано перевірку можливості відкриття й закриття люків і дверей, випуску й збирання шасі, перевірку відсутності заїдань механічної проводки системи штурвального управління (СШУ). Зауважень до фрункціонування у перевірених агрегатів немає.

Щодо літака Ан-158 для забезпечення міцності у зв'язку з ростом навантаження виконані посилення конструкції крила та фююзеляжу. При цьому статична міцність забезпечена на рівні літака Ан-148-100.

\section{Забезпечення ресурсу й термінів служби}

Визначення умов відпрацьовування літаками сімейства Ан-148-100/Ан-158 проектного терміну служби 30 років виконано на основі порівняльного аналізу корозійної стійкості конструкцій літаків «Ан», термін служби яких перевищує 30 років, і рекомендацій ЦАГІ.

Літаки Ан-148-100/Ан-158 спроектовані і виготовляються у всекліматичному виконанні з дотриманням усіх вимог щодо антикорозійного захисту при цьому виді виконання.

У силовій конструкції літаків Ан-148-100/Ан-158 застосовані пресовані, катані й ковані напівфабрикати із традиційних сплавів Д16Т, Д16чТ, з нових сплавів 1161T, 1163Т, 1933Т3, а також із традиційного сплаву В95пч, термообробленого за режимом Т2.

Порівняно з літаками Ан-12, Ан-22, Ан-24, Ан-26, Ан-30, що досягли терміну служби 40-45 років, вибір матеріалів і режимів їх термообробки визначався прагненням без шкоди для характеристик витривалості й тріщиностійкості поліпшити корозійну стійкість силової конструкції літака.

Так, верхні панелі центроплана й кінцевих частин крила (КЧК) виготовлені відповідно із пресованих панелей (рисунок 6), а також листів і профілів сплавів 1973 і В95пч, термооброблених за режимом Т2. Верхні ж панелі центроплана, середньої та кінцевої частин (СЧК, КЧК) крила літаків Ан-12, Ан-22, Ан-24, Ан-26, Ан-30 виготовлені з напівфабрикатів сплаву В95, термообробленого за режимом Т1.

Двоступінчастий режим старіння Т2 порівняно 3 одноступінчастим режимом Т1 значно поліпшує опір корозії розшарування й корозійному розтріскуванню напівфабрикатів зі сплавів 1973 і В95 (див. таблицю 1).

Стрингерний набір, що розташований в зоні під підлогою фюзеляжів літаків, порівнюваних 3 літаками Ан-148-100/Ан-158, виготовлений із пресованих профілів сплаву Д16Т, Д16чТ. Досвід експлуатації цих літаків показав недостатню корозійну стійкість профрілів зі сплаву Д16Т, Д16чТ, особливо у відношенні корозії розшарування. Тому на літаках Ан-148-100/Ан-158 увесь стрингерний набір, що розташований під підлогою фюзеляжу, виготовлений 3 листів сплаву В95пчА, термообробленого за двоступінчастим режимом Т2.

Усі високонавантажені кронштейни, фрітинги крила й фрюзеляжу, боковини шпангоутів фюзеляжу в літаках Ан-148-100/Ан-158 виготовлені зі штампувань сплаву 1933Т3. Сплав 1933, термооброблений за двоступінчастим режимом Т3, порівняно зі сплавами АК-6Т1 і В93пчТ1, з яких виготовлені подібні елементи конструкції літаків Ан-12, Ан-22, Ан-24, Ан-26 і Ан-30, значною мірою перевершує останні за опором корозійному розтріскуванню й корозії розшарування (див. таблицю 1).

У конструкції літаків Ан-148-100/Ан-158 використовують матеріали, досвід 
застосування яких у парку літаків «Ан» з терміном служби більше 40 років, не виявив деградації їх властивостей (механічних, опору втомі та тріщиностійкості). Отже, відпрацьовування літаками Ан-148-100/Ан-158 проектного терміну служби 30 років не потребує проведення в експлуатації спеціальних заходів щодо заміни силових елементів або їх посилення з умов деградації матеріалів.

Таблиця 1

\begin{tabular}{|c|c|c|c|c|c|c|c|}
\hline \multirow[b]{2}{*}{$\begin{array}{l}\text { № } \\
\text { п/п }\end{array}$} & \multirow[b]{2}{*}{$\begin{array}{c}\text { Основні силові } \\
\text { елементи } \\
\text { конструкції }\end{array}$} & \multicolumn{3}{|c|}{$\begin{array}{c}\text { Ан-24, Ан-26, Ан-30, } \\
\text { Ан-32, Ан-12, Ан-72, } \\
\text { Ан-74, Ан-22 }\end{array}$} & \multicolumn{3}{|c|}{ Ан-148-100/Ан-158 } \\
\hline & & $\begin{array}{l}\frac{m}{\widetilde{\sigma}} \\
\text { 岳 } \\
\text { v }\end{array}$ & 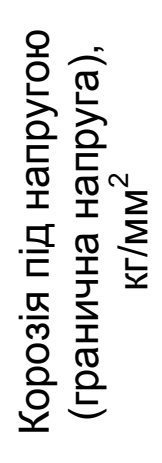 & 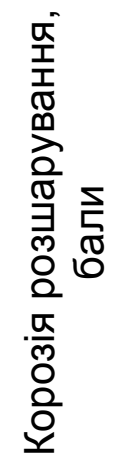 & $\begin{array}{l}\frac{m}{\mathbb{T}} \\
\text { 衣 } \\
\text { v }\end{array}$ & 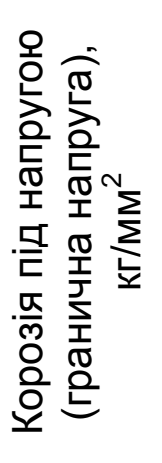 & 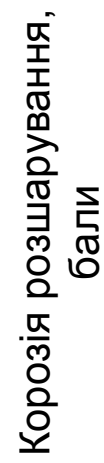 \\
\hline 1 & $\begin{array}{l}\text { Верхні панелі } \\
\text { центроплана, } \\
\text { СЧК, КЧК }\end{array}$ & $\begin{array}{l}\text { В95T1 } \\
\text { В95пчТ1 }\end{array}$ & 5 & $6-7$ & $\begin{array}{l}\text { 1973Т2 } \\
\text { В95пчТ2 }\end{array}$ & 17,5 & $2-3$ \\
\hline 2 & $\begin{array}{l}\text { Нижні панелі } \\
\text { центроплана, } \\
\text { СЧК, КЧК }\end{array}$ & $\begin{array}{l}\text { Д16Т } \\
\text { Д16чТ }\end{array}$ & 5 & $6-7$ & $\begin{array}{l}1161 \mathrm{~T} \\
\text { Д16чТ } \\
1163 Т\end{array}$ & $5-6$ & $6-7$ \\
\hline 3 & $\begin{array}{l}\text { Верхні пояси } \\
\text { лонжеронів крила }\end{array}$ & $\begin{array}{l}\text { В95T1 } \\
\text { В95пчТ1 }\end{array}$ & 5 & $6-7$ & В95пчТ2 & 17,5 & $2-3$ \\
\hline 4 & $\begin{array}{l}\text { Нижні пояси } \\
\text { лонжеронів крила }\end{array}$ & $\begin{array}{l}\text { Д16Т } \\
\text { Д16 }\end{array}$ & 5 & $6-7$ & $\begin{array}{l}\text { Д16чТ } \\
1163 Т\end{array}$ & $5-6$ & $6-7$ \\
\hline 5 & $\begin{array}{l}\text { Пояси лонжеронів } \\
\text { стабілізатора } \\
\text { i кіля }\end{array}$ & $\begin{array}{l}\text { Д16Т } \\
\text { Д16 }\end{array}$ & 5 & $6-7$ & $\begin{array}{l}\text { Д16чТ } \\
1163 Т\end{array}$ & $5-6$ & $6-7$ \\
\hline \multirow{4}{*}{6} & \multirow{4}{*}{$\begin{array}{l}\text { Кронштейни, } \\
\text { фітинги крила і } \\
\text { фрюзеляжу, боко- } \\
\text { вини шпангоутів } \\
\text { фюзеляжу }\end{array}$} & АК6Т1 & $5-6$ & $6-7$ & \multirow{4}{*}{-1933T3 } & \multirow{4}{*}{24} & \multirow{4}{*}{2} \\
\hline & & B93T1 & $5-6$ & $6-7$ & & & \\
\hline & & В93пчТ2 & 15 & 4 & & & \\
\hline & & 1933T3 & 24 & 2 & & & \\
\hline \multirow[t]{2}{*}{7} & \multirow{2}{*}{$\begin{array}{l}\text { Стрингерний } \\
\text { набір фрюзеляжу }\end{array}$} & $\begin{array}{l}\text { Д16Т } \\
\text { Д16чТ } \\
\end{array}$ & & & \multirow[t]{2}{*}{ В95пчАТ2 } & \multirow[t]{2}{*}{17,5} & \multirow[t]{2}{*}{$2-3$} \\
\hline & & 01420 & & & & & \\
\hline
\end{tabular}




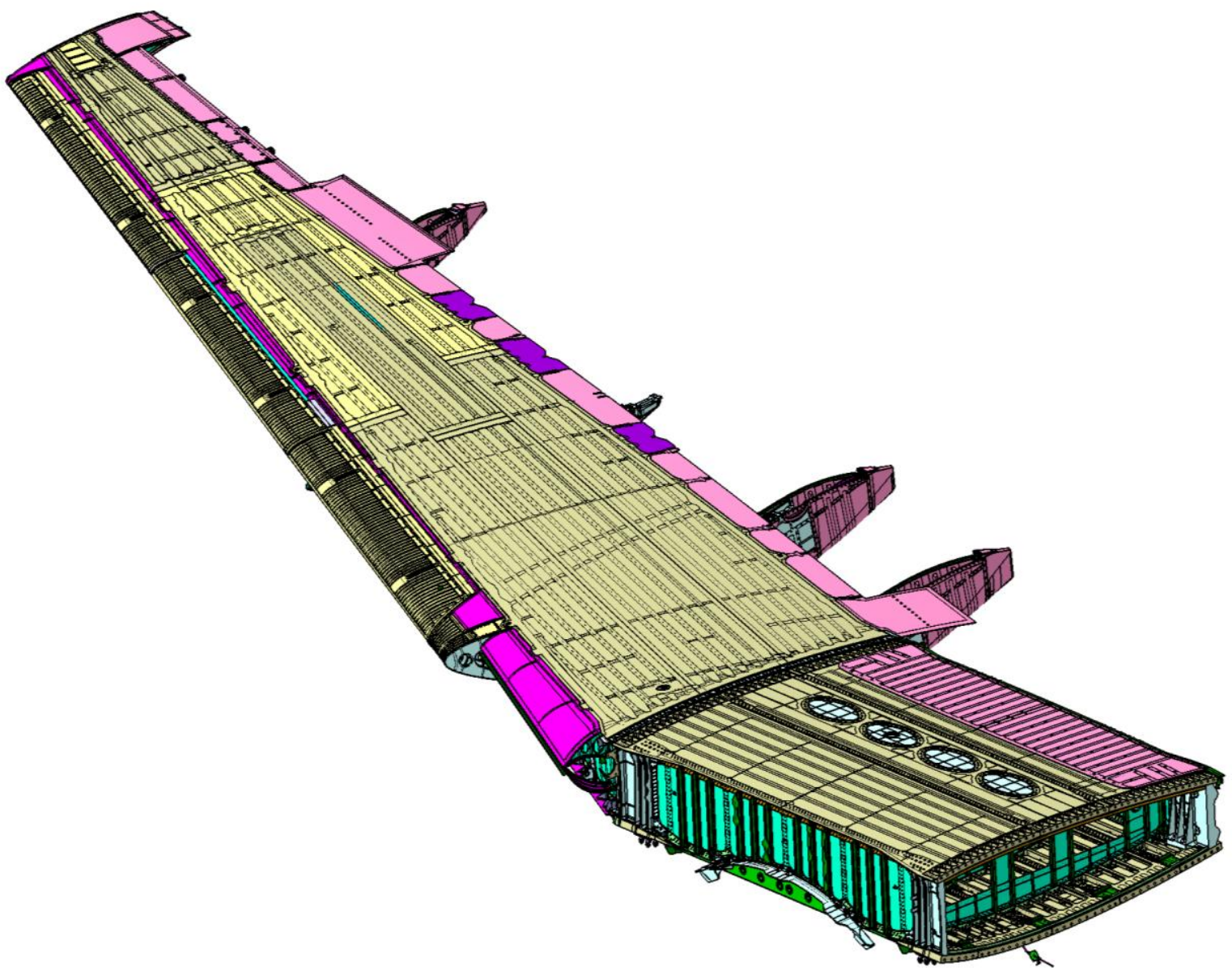

Рисунок 6 - Центроплан та кінцева частина крила

У літаках застосовано ряд конструкторських і технологічних рішень щодо захисту від зниження міцності в процесі експлуатації від атмосферних впливів, корозії й стирання:

1. Більша частина типового стрингерного набору фюзеляжу літаків Ан-148-100/Ан-158 складається із гнутих профрілів Д16АТ і В95пчАТ2. Гнуті профрілі виготовляють із плакованих листів, і завдяки наявності плакування на поверхні листів гнуті профрілі мають підвищену корозійну стійкість порівняно із пресованими профрілями.

2. 3 метою виключення можливого застою води, забезпечення провітрювання й огляду стану обшивки й внутрішнього набору теплозвукоізоляція не приклеюється, як у раніше спроектованих літаках, а підвішується так, щоб був проміжок між нею й обшивкою.

3. Для попередження створення застійних зон (скупчення вологи) у фюзеляжі $є$ дренажні отвори, дренажні клапани й щілини.

4. Компактна водо-вакуумна туалетна система виключає попадання агресивних рідин у простір фрюзеляжу, що розташований під підлогою.

5. При конструюванні знімних лючків, знімних панелей передбачені регламентовані проміжки, що заповнюються герметиком, і забезпечене їх зняття через змащення.

6. Деталі конструкції, що виходять на зовнішній контур, анодуються після припасування, свердління й зенкування отворів. У герметичних відсіках заклепки поставлені на герметику. 
7. Розміщення маршових двигунів і допоміжної силової установки виключає влучення вихлопних газів на силові елементи конструкції.

8. Основним способом захисту від корозії деталей з алюмінієвих сплавів $€$ сірчанокисле анодне окиснення 3 наступним нанесенням лакофрарбового покриву (ЛФП). Товщина анодно-окисного покриття на обшивальних плакованих листах для літаків Ан-148-100/Ан-158 становить 6...12 мкм. На деталях із пресованих напівфрабрикатів, що виходять на зовнішній контур, а також на силових деталях внутрішнього набору відповідального призначення, виготовлених із пресованих напівфабрикатів, - товщина анодно-окисного покриття становить не менш 6 мкм. Товщина анодно-окисного покриття на деталях раніше спроектованих літаків - не менше 4 мкм.

9. Обшивальні листи частини фрюзеляжу в зоні під підлогою, нижні площини крила і оперення, де можлива конденсація й скупчення вологи, мають двостороннє плакування товщиною не менше 40 мкм на кожну сторону.

10. Заклепки всіх агрегатів, за винятком заклепок металізації, піддані анодному окисненню в сірчаній кислоті з наповненням покриття в розчині біхромату калію. Фрезеровані головки заклепок, а також заклепки металізації перед остаточним фарбуванням піддані місцевому хімічному оксидуванню.

11. Деталі баків-кесонів піддані сірко-кислотному анодному окисненню 3 наповненням покриття в розчині біхромату калію. Внутрішня поверхня баківкесонів покрита паливостійким лакофрарбовим покриттям (ґрунтовка ЕП-0215).

12. Для захисту деталей, що виходять на зовнішній контур, застосовані накі варіанти фарбування:

- на основі перхлорвінілових емалей;

- на основі епоксидних емалей;

- на основі поліуретанових емалей.

13. Закриті зони конструкції додатково захищені профілактичним, періодично поновлюваним в експлуатації, антикорозійним складом типу Динітрол.

14. Усі технологічні процеси виготовлення деталей літаків Ан-148/Ан-158, a саме:

- анодування деталей з Al і Ti сплавів;

- оксидування деталей з Al і Mg сплавів;

- кадмування, фросфатування, тверде хромування деталей з конструкційних сталей;

- застосування спеціальних видів хіміко-термічної обробки (азотування, цементація);

- нанесення відповідних ґрунтувальних і лакофарбових покриттів, виконувалися відповідно до вимог всекліматичного виконання.

15. Конструктивно передбачена можливість легкого доступу до закритих зон конструкції:

- фрюзеляж - знімні панелі підлоги, відкидні панелі силового зализу;

- крило - люки-лази на верхніх (для центроплана) і нижніх (для КЧК) панелях кесона крила, відкидні панелі на крилі й зализі крила 3 фюзеляжем;

- оперення - знімні панелі й відкидні панелі на стабілізаторі й кілі.

16. У посібнику 3 технічної експлуатації літаків Ан-148-100/Ан-158 (розділ 51) наведені стандартизовані технологічні процеси видалення корозії й попередження її розвитку. 
Виконано аналіз ефективності прийнятих конструкторських рішень, вибраних конструкційних матеріалів, режимів термообробки й захисних покриттів. Там же визначено припустимі інтервали між оглядами для основних силових елементів і рекомендовано інтервали для включення в Програму технічного обслуговування літака.

Таким чином, можна констатувати, що основні силові елементи типової конструкції літаків Ан-148-100/Ан-158 захищені від зниження або втрати міцності в процесі експлуатації з будь-якої причини, включаючи атмосферні впливи, корозію й стирання, а також забезпечені достатніми засобами вентиляції й дренажування.

Для підтвердження безпеки конструкції, підданої акустичному впливу, виконано оцінку міцності зі втоми при високочастотному навантаженні, викликаному пульсаціями аеродинамічного тиску, що виникають при роботі силової установки Д436-148. Розрахункові дані підтверджені результатами випробувань зразків, агрегатів конструктивно-подібного виконання й досвідом експлуатації літаків прототипів.

Результати проведених робіт дозволяють стверджувати:

- поява тріщин утоми від акустичних навантажень у будь-якій деталі конструкції літака, підданій акустичному впливу, не є ймовірною;

- аварійне або катастрофічне руйнування через тріщини від акустичних навантажень не $є$ ймовірним.

Елементи конструкції фрюзеляжу, крила, пілонів навішення маршових двигунів й оперення літаків Ан-148-100/Ан-158, в яких застосовані матеріали на основі вуглецевих, скляних, органічних, комбінованих волокон і їх текстильних форм із використанням полімерної термореактивної матриці (ПКМ), умовно можна розділити на такі групи:

- виконані зі склопластику або органопластику: обтічник РЛС, обтічники ООС, зализ крила з фююзеляжем, радіопрозорий відсік форкіля, передній обтічник кіля, задня частина стікача кіля, елементи пілонів навішення маршових двигунів, обтічники закінцівок крила, рухливі й нерухливі обичайки обтічників механізмів закрилків, панелі заліза центроплана;

- виконані з вуглепластику: стулки ПОС, поперечні балки підлоги, каркаси інтерцепторів, руль висоти, руль напрямку, панелі хвостової частини крила, кіля й стабілізатора, каркаси елеронів, елементи конструкції закрилків.

До основних силових елементів конструкції можна віднести виконані 3 вуглепластику поперечні балки підлоги, каркаси інтерцепторів, рулі висоти (рисунок 7) й напрямку (рисунок 8), а також елерони.

Агрегати із ПКМ мають такі особливості:

- високий втомний опір при оптимальному змісті волокна в порівнянні 3 металевими сплавами й відсутність впливу фретинг-корозії на утому механічних з'єднань;

- нечутливість міцності й утоми до малих концентраторів напруг, сумірних з поперечним розміром;

- насичення вологою й зниження внаслідок цього як механічних властивостей самого матеріалу, так і несучої здатності конструкцій, особливо при стиску (зсуві) в умовах експлуатаційних температур. 


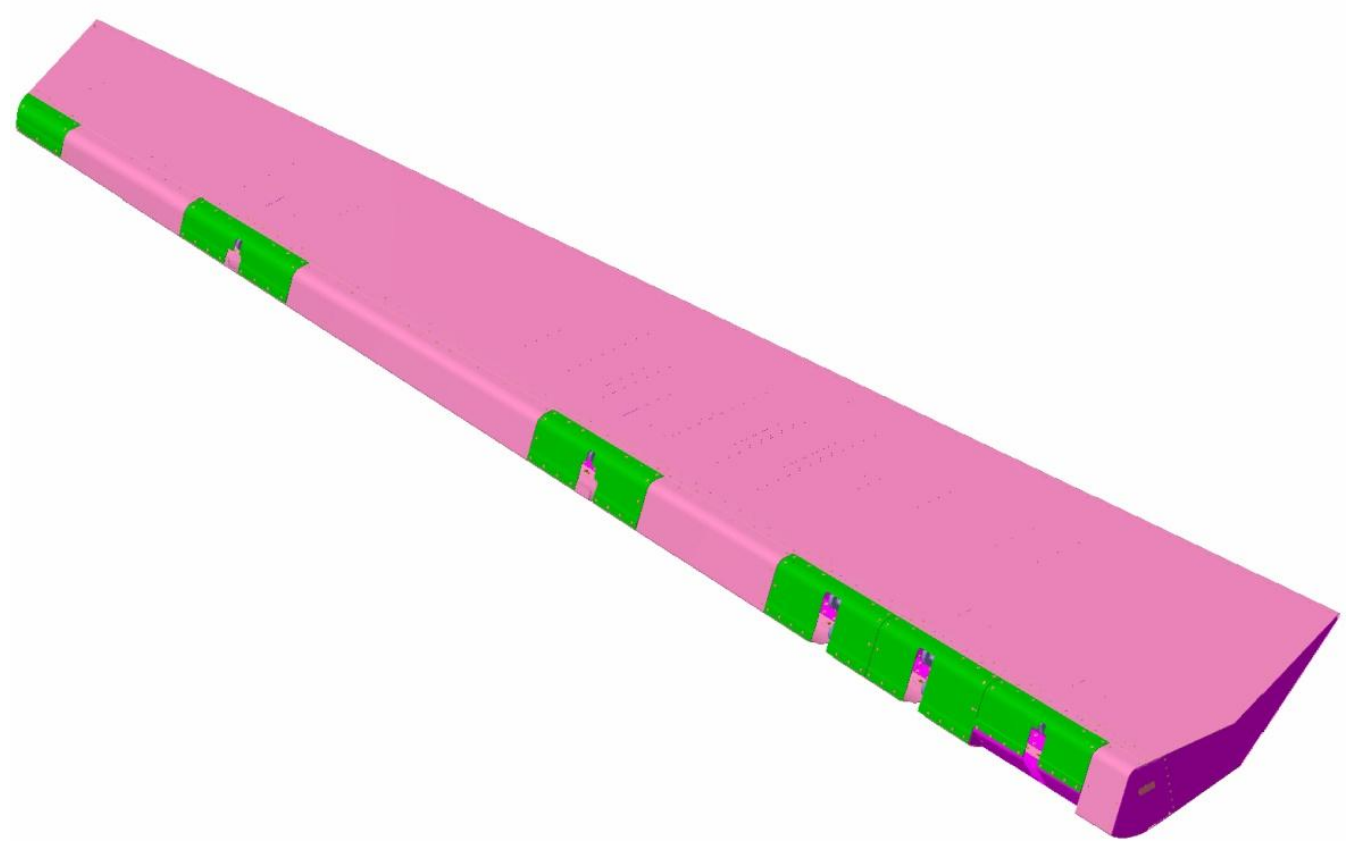

Рисунок 7 - Руль висоти

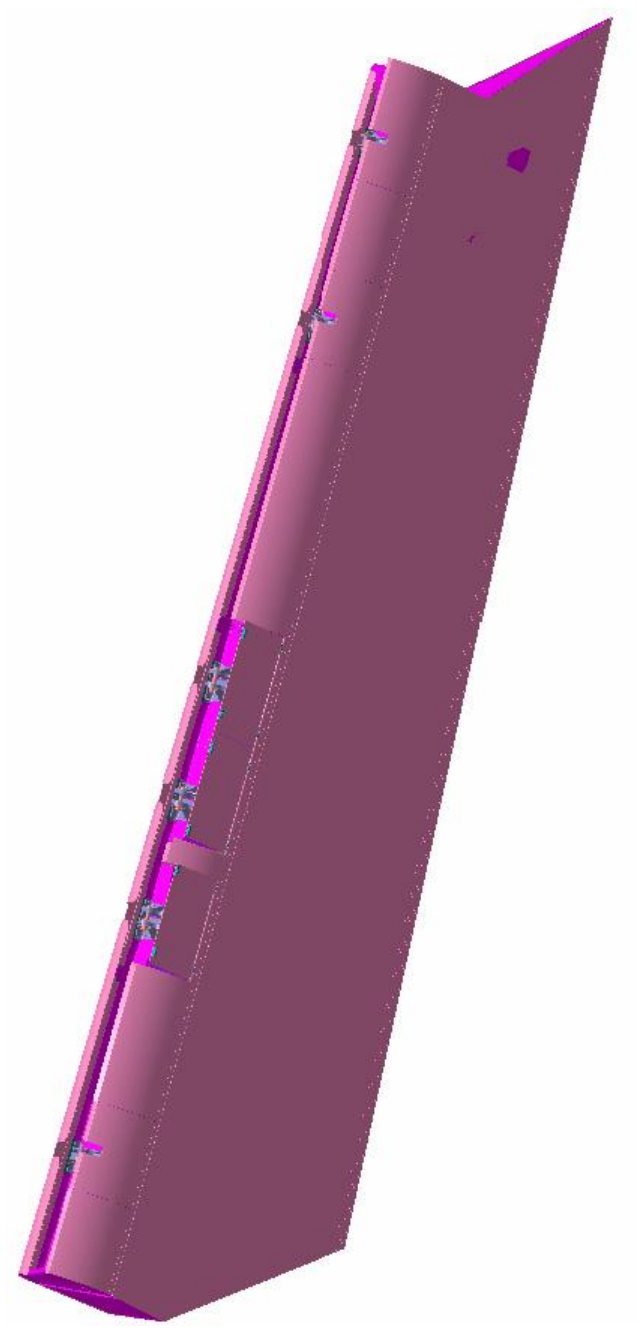

Рисунок 8 - Руль напрямку

При виборі конструктивного виконання зазначених агрегатів використано досвід проектування, побудови й більш ніж 10-літньої експлуатації композитних агрегатів літака Ан-70. Зокрема, застосовано відпрацьовану інтегральну конструкцію, виключено стільниковий заповнювач.

У зв'язку з тим, що на довговічність конструкцій значно впливає навколишнє середовище, для їхнього захисту застосовані ефективні методи захисту поверхонь і особливо торців композиційних деталей від проникнення вологи за допомогою герметиків, лакофрарбових і спеціальних захисних покриттів.

Крім того на довговічність композитних конструкцій впливають локальні ушкодження структури матеріалу від механічних ударів. Для агрегатів із полімерних композиційних матеріалів літаків Ан-148-100/Ан-158 в експлуатації передбачені цільові огляди - як візуальні, так i із застосуванням інструментальних методів контролю (акустичні), - а також розроблені відповідні карти неруйнуючого контролю. 
Для підтвердження можливості відпрацьовування проектних ресурсу й терміну служби агрегатів із ПКМ проводять їхні випробування на втому 3 імітацією типових випадкових ушкоджень при обслуговуванні, а також на залишкову й кліматичну міцність і живучість відповідно до «Комплексного плану робіт із забезпечення міцності й ресурсу конструкції літака Ан-148».

Отже, можна стверджувати, що за результатами проведених робіт, і 3 урахуванням планованих випробувань на міцність забезпечується можливість відпрацювання проектних ресурсу й терміну служби агрегатів із ПКМ.

При забезпеченні й підтримці безпеки експлуатації конструкції літаків Ан-148-100/Ан-158 за умовами міцності при тривалій експлуатації за основу взятий принцип поетапного встановлення й продовження призначених ресурсів і термінів служби, який дозволяє організувати ефективну взаємодію Розроблювача й Експлуатанта авіаційної техніки. Основні положення прийнятого підходу:

- початковий призначений ресурс не перевищує $27 \%$ проектного й становить 20000 льотних годин, 10000 польотів для Ан-148-100A, Ан-148-100B і 8000 польотів для Ан-148-100E, Ан-158. Зазначені величини підтверджені проведеними випробуваннями на утому літака Ан-148-100 № 01-03, і на підставі розрахунку, а також з урахуванням вимоги про співвідношення гранично припустимого напрацювання літака в експлуатації;

- початковий призначений термін служби не перевищує максимально досягнутого для літаків-прототипів терміну служби до першого капітального ремонту (або КВР) і становить 10 років;

- збільшення ресурсів і термінів служби проводять на основі аналізу експлуатаційних даних (службової інфрормації, інформації про виявлені несправності й польотної інформації 3 бортових пристроїв, що реєструють, і РПП-148);

- зчитування, попереднє оброблення (включаючи попередній аналіз) і нагромадження інформації проводять на фрормах оперативного технічного обслуговування;

- передача експлуатаційних даних, що накопичуються, ДП «АНТОНОВ» виконується з періодичністю 1 раз на рік;

- безперервне (за необхідності) уточнення експлуатаційно-технічної документації (ЕД) літака й своєчасне інформування про це Експлуатанта (за необхідності через Авіаційні Департаменти).

Перераховані вище положення знайшли відбиття в експлуатаційній документації (ЕД) літаків Ан-148-100/Ан-158. Відпрацьовування проектних ресурсів (термінів служби) проводять поетапно. Діючі етапи відпрацьовування проектних ресурсів (термінів служби) вказують у розділі «Обмеження льотної придатності» КЛЕ. ДП «АНТОНОВ» забезпечує випереджальне збільшення ресурсів (термінів служби) діючого етапу шляхом підготовки необхідних доказових документів відповідно до вимог АП і подання їх в Авіарегістр МАК і Державіаслужбу України.

У розділі 04 КЛЕ «Обмеження льотної придатності» установлені спеціальні вимоги за умовами експлуатації основних силових елементів конструкції літака, які забезпечують можливість виявлення випадкових i корозійних ушкоджень, в окремих випадках виявлення ушкоджень від втоми. Для діючого етапу відпрацьовування проектного ресурсу встановлюють 
припустимі напрацювання для планера, навішення двигунів, шасі й механічних елементів системи їх збирання-випуску, механічних елементів системи керування й зміни конфрігурації, елементів конструкції, що забезпечують взаємне силове стикування частин планера й агрегатів літака.

Для конструкції літаків (силових елементів і критичних місць конструкції) періодичне технічне обслуговування (ТО) містить такі фрорми:

- форма sA. Виконується через кожні 300 польотів або 6 місяців;

- форма sC. Виконується через кожні 3000 польотів або 36 місяців;

- роботи з індивідуальних Програм контролю старіння. Виконуються для літаків, що досягли 15000 польотів або 10 років, на формах, кратних sC.

ДП «АНТОНОВ» забезпечує безпеку експлуатації літаків у межах зазначеного ресурсу ( терміну служби) шляхом:

- внесення уточнень ЕД;

- випуску бюлетенів, переліків замін деталей (одиниць устаткування), що мають обмежений ресурс (термін служби), технічної документації (ТД) на ремонти й доопрацювання (за необхідності);

- видачі рекомендацій з технічної експлуатації літака при виявленні десектів, що виходять за рамки ЕД;

- розроблення індивідуальних Програм контролю старіння кожного екземпляра літака;

- інфрормаційної підтримки експлуатації літаків.

Для забезпечення відпрацьовування проектного ресурсу й випереджального зняття обмежень відповідно до вимоги буде проведений комплекс випробувань на втому, випробувань на втому й фрункціонування, живучості й залишкової міцності. При цьому забезпечується подвійне випереджувальне напрацювання конструкції при випробуваннях на втому щодо нальоту літаків парку.

Таким чином, можна стверджувати, що підготовлені прийнятні Інструкції 3 підтримки льотної придатності. При цьому льотна придатність у частині забезпечення ресурсу (терміну служби) забезпечується за умови виконання Експлуатантом:

- вимог експлуатаційної документації (ЕД);

- робіт з індивідуальних Програм контролю старіння на трудомістких формах ТО для літаків, що досягли 15000 польотів або 10 років;

- надання Експлуатантом літака для аналізу в ДП «АНТОНОВ» інформації про наліт літака в годинах й польотах, відмовах і несправностях, умовах експлуатації, у тому числі за даними РПП і бортового реєстратора БУР-95-02. У випадках несвоєчасного й неповного інформування ДП «АНТОНОВ» використовують консервативний підхід при збільшенні призначених ресурсів і термінів служби.

Проведені оцінки міцності показують, що аварійної або катастрофрічної ситуації через утому, корозію, дефекти виробництва або випадкового ушкодження можна уникнути протягом усього часу експлуатації літаків.

Щодо літака Ан-158 проектний ресурс і термін служби планера при експлуатації за технічним станом відповідають аналогічним даним літака Ан-148-100Е і забезпечуються шляхом проведення відповідних доробок силових елементів. Відпрацьовування ресурсів і терміну служби виконується відповідно до експлуатаційної документації літака.

Нижче наведено перелік технічних звітів, інженерних аналізів і технічних довідок із міцності, ресурсу та термінів служби літаків Ан-148-100/Ан-158: 
- Літак Ан-148. Розрахунок зовнішніх навантажень.

- Літак Ан-148-100 (моделі Ан-148-100A, Ан-148-100В, Ан-148-100Е). Обґрунтування статичної міцності конструкції. Зведені дані.

- Звіт про статичні випробування крісла інспектора літака Ан-148, вузлів кріплення крісла та прив'язної системи AM SAFE 4137-1-0113577 до дверей в кабіну екіпажу.

- Звіт про статичні випробування крісла бортпровідника Ан-148-100, вузлів кріплення крісла та вузлів кріплення прив'язної системи АМ SAFE model 4057.

- Звіти про статичні випробування пасажирських крісел фрірми «Geven».

- Літак Ан-148-100 (моделі Ан-148-100A, Ан-148-100B, Ан-148-100Е). Обґрунтування відповідності статичної міцності конструкції кесона крила вимогам Сертифікаційного базису СБ148 (Зведені матеріали).

- Літак Ан-148-100 (моделі Ан-148-100А, Ан-148-100В, Ан-148-100Е). Обґрунтування відповідності статичної міцності конструкції механізації крила вимогам СБ-148 (Зведені матеріали).

- Літак Ан-148-100 (моделі Ан-148-100A, Ан-148-100B, Ан-148-100E). Обґрунтування відповідності статичної міцності конструкції оперення вимогам СБ-148 (Зведені матеріали).

- Літак Ан-148-100 (моделі Ан-148-100А, Ан-148-100B, Ан-148-100Е). Шасі. Зведені матеріали щодо обґрунтування міцності. Інженерний аналіз.

- Літак Ан-148-100. Розрахунок на міцність гідроагрегатів.

- Літак Ан-148-100 (моделі Ан-148-100A, Ан-148-100B, Ан-148-100Е). Зведені матеріали зі статичної міцності силової установки (СУ).

- Літак Ан-148-100 (моделі Ан-148-100A, Ан-148-100B, Ан-148-100E). Обґрунтування відповідності статичної міцності конструкції пілона навішування МДУ вимогам СБ-148 (зведені матеріали).

- Літак Ан-148-100. Обґрунтування відповідності статичної міцності конструкції фрюзеляжу й обладнання, встановленого в фрюзеляжі, вимогам СБ-148. Інженерний аналіз.

- Літак Ан-148-100 (моделі Ан-148-100А, Ан-148-100В, Ан-148-100Е). Обґрунтування відповідності статичної міцності конструкції крісел пілотів, інструктора, бортпровідників, їх прив'язних систем і вузлів установки, а також каркаса фююзеляжу в зоні установки крісел вимогам СБ-148. Інженерний аналіз.

- Літак Ан-148-100. Зведені матеріали щодо обґрунтування міцності основної силової конструкції проводки управління літака типу Ан-148100, моделі Ан-148-100A, Ан148-100B, Ан-148-100Е. Інженерний аналіз.

- Літак Ан-148-100 (моделі Ан-148-100А, Ан-148-100B і Ан-148-100E). Устаткування багажно-вантажних відсіків (Зведені матеріали 3 міцності).

- Результати копрових випробувань на роботоємність і багаторазові скидання передньої опори шасі літака Ан-148.

- Результати копрових випробувань на роботоємність і багаторазові скиди основної опори шасі літака Ан-148.

- Літак Ан-148-100. Сертифікаційні льотні випробування із дослідження закономірностей навантаження агрегатів планера в діапазоні експлуатаційних обмежень і на граничних за умовами міцності режимах. Технічний звіт. 
- Літак Ан-148-100 (моделі Ан-148-100А, Ан-148-100В, Ан-148-100Е). Сертифікаційні льотні випробування із визначення вібраційної і бафтингової безпеки. Технічний звіт.

- Висновок щодо відповідністі матеріалів, котрі використовуються в типовій конструкції літака Ан-148-100 (моделі Ан-148-100А, Ан-148-100B, Ан-148-100Е), вимогам п.п.25.603, 25.609 і 25.613 Сертифікаційного Базису СБ- 148.

- Літак Ан-148-100. Оцінка відповідності конструкції при пошкодженні нелокалізованими уламками двигунів вимогам 25.571 (е) СБ-148.

- Літак Ан-148-100 (моделі Ан-148-100A, Ан-148-100В, Ан-148-100Е). Оцінка міцності захисту від розльоту нелокалізованих уламків ВСУ, яка встановлюється на протипожежному екрані.

- Літак Ан-148-100 (моделі Ан-148-100А, Ан-148-100В, Ан-148-100Е). Обґрунтування міцності конструкції при пошкодженні від зіткнення 3 птахом відповідно до вимог 25.571 (е) (1) і 25.631 СБ-148 (крило, пілон навішування МДУ, оперення).

- Літак Ан-148-100 (моделі Ан-148-100А, Ан-148-100В, Ан-148-100Е). Обґрунтування міцності конструкції при пошкодженні від зіткнення 3 птахом відповідно до вимог 25.571 (е) (1) і 25.631 СБ-148 (фюзеляж і лобове скло ліхтаря кабіни).

- Скло лобове ТСК 008У.01.000. Звіт про результати стендових динамічних випробувань.

- Літак Ан-148-100 (моделі Ан-148-100А, Ан-148-100В, Ан-148-100Е). Обґрунтування відповідності статичної міцності герметичної кабіни фрюзеляжу вимогам СБ-148. Інженерний аналіз.

- Літак Ан-148-100 (моделі Ан-148-100А, Ан-148-100В, Ан-148-100Е). Обґрунтування відповідності статичної міцності конструкції фююеляжу в разі аварійної посадки на землю вимогам СБ-148. Інженерний аналіз.

- Літак Ан-148-100 (моделі Ан-148-100A, Ан-148-100В, Ан-148-100Е). Обґрунтування відповідності статичної міцності конструкції фюзеляжу в разі аварійної посадки на воду вимогам СБ-148. Інженерний аналіз.

- Літак Ан-148-100. Керівництво з льотної експлуатації.

- Літак Ан-148-100. Льотне керівництво.

- Літак Ан-148-100. Керівництво із завантаження та центрування.

- Технічні умови на виготовлення, контроль, приймання та постачання літака Ан-148 № 01-03, призначеного для проведення випробувань на міцність.

- Літак Ан-148-100 № 01-03. Аналіз причин руйнування конструкції фюзеляжу при проведенні статичних випробувань. Обґрунтування достатності виконаних підсилень типової конструкції фрюзеляжу. Інженерний аналіз.

- Кесон крила. Зведені матеріали зі статичної міцності

- Пілон. Зведені матеріали зі статичної міцності.

- Механізація крила. Зведені матеріали зі статичної міцності.

- Зведені матеріали зі статичної міцності фюзеляжу й обладнання, що встановлюється в фрюзеляжі.

- Оперення. Зведені матеріали зі статичної міцності.

- Шасі. Зведені матеріали зі статичної міцності.

- Літак Ан-148-100. Технічний звіт. Розрахунок спектрів перевантажень 
і втомних навантажень на елементи конструкції в прогнозованих умовах типової експлуатації.

- Літак Ан-148-100. Сертифрікаційні наземні випробування із визначення основних експлуатаційно-технічних характеристик. Технічний звіт.

- Літак Ан-148-100. Спеціальні сертифікаційні льотні випробування із визначення статистичних характеристик повторюваності навантажень на режимах типової експлуатації. Технічний звіт.

- Літак Ан-148. Перелік особливо відповідальних конструктивних елементів.

- Звіт про результати тензометрії літака Ан-148-100 № 01-03 при проведенні випробувань із втомленості.

- Звіт про результати випробувань на втому літака Ан-148 № 01-03.

- Літак Ан-148-100. Програма випробувань на втому літака Ан-148-100 № 01-03. ДП АНТК ім. О.К. Антонова, ПЗ № 615, ЦАГІ, СЦ «ЦАГІTECT».

- Літак Ан-148-100. Пояснювальна записка до Програми № 148.00.0132.006 ПМ випробувань на втому літака Ан-148-100 № 01-03.

- Літак Ан-148. Програма випробувань на витривалість і функціональну працездатність механізмів збирання-випуску шасі та механізмів стулок шасі літака. ДП АНТК ім. О.К. Антонова.

- Літак Ан-148. Програма випробувань системи повороту стояка П.О.С. на ресурс і функціонування.

- Літак Ан-148-100 (моделі Ан-148-100A, Ан-148-100В, Ан-148-100Е). Висновок про встановлення початкового призначеного ресурсу 20000 льотних годин, 10000 польотів, 10 років особливо відповідальних елементів, вузлів і агрегатів функціональних систем шасі за умовами втомної міцності та функціонування при тривалій експлуатації.

- Літак Ан-148-100 (моделі Ан-148-100А, Ан-148-100В, Ан-148-100E). Обґрунтування висновку про встановлення початкового призначеного ресурсу 20000 льотних годин, 10000 польотів, 10 років особливо відповідальних елементів, вузлів і агрегатів функціональних систем шасі літака за умовами втомної міцності і фрункціонування.

- Літак Ан-148-100. Висновок про відповідність типової конструкції літака Ан-148-100 вимогам Сертифікаційного Базису СБ-148 за умовами безпеки від фолатера, реверсу та дивергенції.

- Літак Ан-148-100. Обґрунтування проектного ресурсу крила.

- Літак Ан-148-100. Розрахунок еквівалентів між навантаженнями при випробуваннях на втому за Програмою № 148.00.0132.006 ПМ і навантаженнями в очікуваних умовах експлуатації.

- Літак Ан-148-100. Обґрунтування проектного ресурсу фрюзеляжу.

- Літак Ан-148-100. Обґрунтування проектного ресурсу оперення.

- Літак Ан-148-100. Аналіз залишкової міцності та рівнів напружень конструкції крила, пілона навішування МДУ й оперення для визначення допустимості пошкоджень (безпечного руйнування) відповідно до 25.571 (a), (b) СБ-148. Інженерний аналіз.

- Літак Ан-148-100. Обґрунтування проектного ресурсу пілона, навішування двигуна Д436-148Б і навішування BCУ Al-450-MC.

- Літак Ан-148-100. Обґрунтування проектного ресурсу закрилків, передкрилків та носків, що відхиляються. 
- Літак Ан-148-100. Обґрунтування проектного ресурсу руля висоти, руля напряму, елерона й інтерцепторів з елементами їх навішування.

- Літак АН-148-100. Обґрунтування проектного ресурсу шасі.

- Літак АН-148-100. Розрахунок втомної довговічності стояків шасі.

- Літак Ан-148-100. Обґрунтування проектного ресурсу механічної проводки СШУ в кабіні екіпажу та системи управління закрилками, передкрилками та носками, що відхиляються.

- Літак Ан-148-100. Програма випробувань на опір втомі та функціональну працездатність носка, що відхиляється, та передкрилка літака спільно з механічною системою управління.

- Літак Ан-148-100. Програма випробувань на опір втомі та функціональну працездатність закрилка літака спільно з механічною системою управління.

- Літак Ан-148-100. Програма випробувань на опір втоми і функціональну працездатність руля висоти 3 елементами його навішування i управління.

- Літак Ан-148-100. Програма випробувань на втому та функціонування механічної проводки системи штурвального управління в Ф1.

- Літак Ан-148-100. Документ з планування технічного обслуговування (ДПТО / MPD).

- Перелік матеріалів основних силових елементів літака Ан-148-100.

- Літак Ан-148-100. Обґрунтування проектного терміну служби 30 років конструкції літака за умовами корозійної міцності.

- Зведені дані щодо оцінювання втомної міцності при акустичних навантаженнях.

- Літак Ан-148-100. Вихідні дані для планування технічного обслуговування.

- Літак Ан-148-100. Регламент технічного обслуговування.

- Літак Ан-148-100. Програма випробувань на втому основної та передньої опор літака.

- Літак Ан-148-100. Програма випробувань на опір втоми пілона та навішування двигуна Д-436-148Б.

- Літак Ан-148-100 (Моделі Ан-148-100А, Ан-148-100В, Ан-148-100Е). Оцінка залишкової міцності конструкції фрюзеляжу при регламентованих пошкодженнях. Інженерний аналіз.

- Літак Ан-148 (моделі Ан-148-100A; Ан148-100B; Ан-148-100E). Обґрунтування відповідності конструкції кріплення двигуна Д-436-148 вимогам сертифрікаційного базису СБ-148 п.25.571 (a), (b). [Аналіз допустимості пошкоджень (безпечного руйнування)] Технічна довідка.

- Літак Ан-148 (моделі Ан-148-100A; Ан148-100В; Ан-148-100Е). Аналіз зміни ресурсних характеристик літаків 3 різними системами автоматичного регулювання тиску (САРТ).

- Висновок про відповідність літака Ан-158 вимогам Сертифрікаційного базису СБ148 за умовами статичної міцності.

- Висновок про відповідність літака типу Ан-148-100 (модель Ан-158) у зв'язку з введенням Головної зміни типової конструкції «Збільшення максимальної посадкової ваги до 38800 кгс» вимогам Сертифікаційного базису СБ-148 за умовами статичної міцності.

- Висновок про відповідність літака типу Ан148-100 (модель Ан-158) 
вимогам Сертифрікаційного базису СБ-148 за умовами міцності конструкції при тривалій експлуатації при збільшенні максимальної посадкової ваги до 38800 кгс.

- Літак Ан-158 Обґрунтування проектного ресурсу та терміну служби 80000 льотних годин, 30000 польотів, 30 років за умовами міцності при тривалій експлуатації.

- Літак Ан-158 Висновок про відповідність типової конструкції літака Ан-158 вимогам Сертифікаційного базису СБ-148 за умовами безпеки від фолатера, реверсу та дивергенції.

- Літак Ан-158 Висновок про відповідність типової конструкції літака Ан-158 вимогам Сертифікаційного базису СБ-148 та встановлення йому початкових призначених ресурсу та терміну служби 20000 льотних годин, 8000 польотів, 10 років за умовами міцності конструкції при тривалій експлуатації.

Всі ці звіти входять до переліку необхідної доказової документації при подальшій сертифікації літака.

\section{Список літератури}

1. Нормы летной годности самолетов транспортной категории (АП-25). - М.: МАК, 1994. - 322 c.

2. Гребеников, А.Г. Методология интегрированного проектирования и моделирования сборных самолетных конструкций [Текст]: монография / А.Г. Гребеников. - Харьков: Нац. аэрокосм. ун-т «ХАИ», 2006. - 532 с.

3. Кива, Д. С. Научные основы интегрированного проектирования самолетов транспортной категории [Текст]: монография / Д. С. Кива, А. Г. Гребеников. Харьков: Нац. аэрокосм. ун-т им. Н.Е. Жуковского «Харьк. авиац. ин-т», 2014. Ч. 1. - 439 с.; - Ч. 2. - 326 с.; - Ч. 3. - 376 с.

4. Конструктивно-технологические методы повышения усталостной долговечности элементов конструкции планера самолета в зоне фуункциональных отверстий [Текст] / Д.С. Кива, Г.А. Кривов, А.Г. Гребеников и др. - Киев: КВИЦ, 2015. - $188 \mathrm{c}$.

5. Гребеников, В.А. Обеспечение усталостной долговечности элементов конструкции планера самолета в зоне разъемных болтовых соединений [Текст]: монография / В.А.Гребеников. -Харьков: Нац. аэрокосм. ун-т им. Н.Е. Жуковского «Харьк. авиац. ин-т», 2010. - 188 с.

6. Интегрированное проектирование и моделирование высокоресурсных растянутых панелей крыла транспортного самолета [Текст]: монография / А.Г.Гребеников, Е.Т. Василевский, В.А. Матвиенко, А.М. Гуменный, С.П. Светличный. - Харьков: Нац. аэрокосм. ун-т им. Н.Е. Жуковского «Харьк. авиац. ин-т», 2011. - 192 с.

7. Осташ, О.П. Механіка руйнування і міцність матеріалів [Текст]: довід. посіб. / О.П. Осташ, В.М. Федірко, В.М. Учанін, С.А. Бичков та ін. / за заг. ред. В.В. Панасюка; за ред. О.П. Осташа, В.М. Федірка. - Львів: Сполом, 2007. - Т. 9: Міцність і довговічність авіаційних матеріалів та елементів конструкцій. - 1068 с. 


\section{References}

1. Normy letnoj godnosti samoletov transportnoj kategorii (AP-25). - M.: MAK, 1994. $-322 \mathrm{~s}$.

2. Grebenikov, A.G. Metodologija integrirovannogo proektirovanija i modeli-rovanija sbornyh samoletnyh konstrukcij [Tekst]: monografija / A.G. Grebenikov. - Har'kov: Nac. ajerokosm. un-t «HAl», 2006. - $532 \mathrm{~s}$.

3. Kiva, D. S. Nauchnye osnovy integrirovannogo proektirovanija samoletov transportnoj kategorii [Tekst]: monografija / D. S. Kiva, A. G. Grebenikov. - Har'kov: Nac. ajerokosm. un-t im. N.E. Zhukovskogo «Har'k. aviac. in-t», 2014. - Ch. 1. - 439 s.; - Ch. 2. -326 s.; - Ch. 3. -376 s.

4. Konstruktivno-tehnologicheskie metody povyshenija ustalostnoj dolgovechnosti jelementov konstrukcii planera samoleta $v$ zone funkcional'nyh otverstij [Tekst] / D.S. Kiva, G.A. Krivov, A.G. Grebenikov i dr. - Kiev: KVIC, 2015. - 188 s.

5. Grebenikov, V.A. Obespechenie ustalostnoj dolgovechnosti jelementov konstrukcii planera samoleta $\mathrm{v}$ zone raz\#emnyh boltovyh soedinenij [Tekst]: monografija / V.A. Grebenikov. - Har'kov: Nac. ajerokosm. un-t im. N.E. Zhukovskogo «Har'k. aviac. in-t», 2010. - $188 \mathrm{~s}$.

6. Integrirovannoe proektirovanie i modelirovanie vysokoresursnyh rastjanutyh panelej kryla transportnogo samoleta [Tekst]: monografija / A.G. Grebenikov, E.T. Vasilevskij, V.A. Matvienko, A.M. Gumennyj, S.P. Svetlichnyj. - Har'kov: Nac. ajerokosm. un-t im. N.E. Zhukovskogo «Har'k. aviac. in-t», 2011. - $192 \mathrm{~s}$.

7. Ostash, O.P. Mehanika rujnuvannja i micnist' materialiv [Tekst]: dovid. posib. / O.P. Ostash, V.M. Fedirko, V.M. Uchanin, S.A. Bichkov ta in. / za zag. red. V.V. Panasjuka; za red. O.P. Ostasha, V.M. Fedirka. - L'viv: Spolom, 2007. - T. 9: Micnist' i dovgovichnist' aviacijnih materialiv ta elementiv konstrukcij. - $1068 \mathrm{~s}$.

Надійшла до редакції 21.12.2018, розглянута на редколегії 22.12.2018.

\section{Structural and Technological Solutions Intended to Provide Static Strength and Lifetime of Regional Passenger Aircraft}

Ensuring flight safety and aircraft structure lifetime is important today's problem in development of up-to-date regional passenger aircraft. This paper deals with the aspects of providing static strength and lifetime of regional passenger aircraft. A series of factors and parameters were analyzed, which affect the aircraft static strength, lifetime, such as: fatigue, corrosion, wear, fretting-corrosion, human factor. To ensure static strength, operational and design loads were determined for the entire range of design speeds and flight altitudes, overloads, aircraft weights and CG positions, fuel weight, cargo weight and various possible combinations of their distribution, taking into account the following: dynamic load and elastic characteristics of the aircraft's design flying in disturbed air and while landing; dynamic load of the control system structure during maneuvering and under wind gusts; failures and malfunctions of systems that directly affect the strength characteristics. The results of flight tests showed that the An-148 100 / An-158 typical structure under the terms of static strength does not have features and parts that create emergency conditions or are unreliable, and confirmed the correctness of the choice of the established operational limitations presented for inclusion in the Flight Operation Manual. 
Conditions for operation of the An-148-100 / An-158 family during a design life of 30 years were determined on the basis of a comparative analysis of the corrosion resistance of the aircraft structures, whose service life exceeds 30 years. An-148-100 / An-158 airplanes are designed and manufactured in all-climate version in compliance with all the requirements for anti-corrosion protection. The aircraft used design and technological solutions to protect against loss of strength during operation from weathering, corrosion and abrasion, which allowed to state that the main power elements of the An-148-100 / An-158 aircraft typical structure are protected from reduction or loss of strength in operation for any reason, including weathering, corrosion and abrasion, as well as adequate ventilation and drainage. The provision of static strength and lifetime of regional passenger aircraft is confirmed by static, fatigue and flight tests of airplanes, reflected in technical reports with regard to strength, lifetime and service life of the An-148-100 / An-158 aircraft.

Keywords: regional passenger aircraft, constructive \&amp; technological method, static strength, lifetime.

\section{Відомості про авторів:}

Донець Олександр Дмитрович - Президент ДП «АНТОНОВ», м. Київ

Семенець Олександр Іванович - канд. техн. наук, Головний конструктор по міцності, вчений секретар НТР ДП «Антонов», м. Київ, Україна.

Василевський Євген Тимофійович - канд. техн. наук, доц., заступник Головного конструктора з крила і оперення, ДП «Антонов», м. Київ, Україна.

Гребеніков Олександр Григорович - д-р техн. наук, проф., зав. каф. 103 «Проектування літаків та вертольотів», Національний аерокосмічний університет ім. М. Є. Жуковського «Харківський авіаційний інститут», Україна.

Гуменний Андрій Михайлович - канд. техн. наук, доц. каф. 103 «Проектування літаків та вертольотів», Національний аерокосмічний університет ім. М. Є. Жуковського «Харківський авіаційний інститут», Україна. 